\title{
Characterization of Blend PA6 +EPDM (60/40) by Tensile Tests
}

\author{
LARISA CHIPER TITIRE ${ }^{1}$, ANDREEA ELENA MUSTEATA ${ }^{1,2}$, \\ ALINA CIOROMILA (CANTARAGIU) ${ }^{3}$, GEORGE CATALIN CRISTEA ${ }^{1,4}$, \\ GEORGE GHIOCEL OJOC ${ }^{1}$, LORENA DELEANU ${ }^{1 *}$ \\ 1"Dunarea de Jos" University, Faculty of Engineering, Department of Mechanical Engineering, 111 Domneasca Str., 800008, \\ Galati, Romania \\ ${ }^{2}$ DMT Marine Equipment, 13C Prelungirea Foltanului Str., 807325, Vanatori, Galati, Romania \\ 3"Dunarea de Jos" University, Faculty of Sciences and Environment, Department of Chemistry, Physics and Environment, \\ 111 Domneasca Str., 800008, Galati, Romania \\ ${ }^{4}$ National Institute for Aerospace Research "Elie Carafoli" (INCAS), Advanced Materials and Tribology Department, 220 \\ Iuliu Maniu Av., 061126, Bucharerst, Romania
}

\begin{abstract}
This paper presents a characterization of PA6 and the blend PA6+EPDM (60/40) by tensile tests in order to evaluate several mechanical properties for impact resistance applications. Results were found to be dependend on test rate $(10 \mathrm{~mm} / \mathrm{min}, 250 \mathrm{~mm} / \mathrm{min}$ and $1000 \mathrm{~mm} / \mathrm{mm})$. SEM investigation point out a homogenous structure. The blend has better value of energy at break, for the higher test speed: for $v=250 \mathrm{~mm} / \mathrm{min}$ this characteristic has the value of energy at break $29.7 \mathrm{~J}$ and the blend has $76.3 \mathrm{~J}$. At $1000 \mathrm{~mm} / \mathrm{min}$, PA6 has this charcateristic of $20 \mathrm{~J}$, but for the blend, it is almost insensitive for the two higher test speeds (76.3 J at $250 \mathrm{~mm} / \mathrm{min}$ and $72.4 \mathrm{~J}$ at $1000 \mathrm{~mm} / \mathrm{min}$, respectively) as compared to the neat polymer that decreases this feature when thr test spee increases. At the lowest teste speed, the values of energy at break for the materials in this study are close (90.2 J for PA6 and $87.7 \mathrm{~J}$ for the blend). The results from tensile tests pointed out that the formulated blend is recommended for impact resistance applications.
\end{abstract}

Keywords: PA6, EPDM, blend, tensile test, strength at break, strain at break, energy at break, Young modulus

\section{Introduction}

The journal only publishes novel, high-quality original research papers. Special issues of selected, peer-reviewed papers from scientific meetings, workshops, conferences on the science, technology and, engineering and emergent subjects will be also published.

The introduction will contain, clearly and concisely, the selective presentation of the scientific information concerning the subject as a support for the original elements of the paper.

This paper template, created in MS Word, provides authors with most of the formatting specifications needed for preparing electronic versions of their contributions. All standard components have been specified for the reasons to easer use when formatting individual paper which facilitates the electronic processing, and the conformity of the journal style. Margins, line spacing, and type styles are included; examples of the type styles are provided throughout this document and are identified in red color. Some components, such as multi-leveled equations, schema, etc. are not prescribed, although a few various styles are provided. The authors will need to incorporate applicable criteria that follow.

Polymer blends, simple (two components) and complex are of interest for industry, thus, research in this domain has been advancing rapidly, as, for instance, the boost given by Toyota research group for PA6. Another advantage of introducing polymer blends on the market is that their processing technologies are the same or very similar to those for neat polymer, the mixing in the melting state being the most commonly used [1-5]. The properties of the polymeric blends are strongly influenced by the developed morphology and the behavior of the interfaces among constituents, but also by processing parameters and treatments $[6,7]$.

$\overline{\text { *email: lorena.deleanu@ugal.ro }}$ 
Polyamides (PA) are thermoplastic polymers, with very diversificate applications (as fibre, films, fabrics and machine components obtained by injection molding) due to their thermal and mechanical properties. But the engineer has to take into account several desadvantages like liquid swelling, impact sensitivity when the component has high stress concentrators and a poor dimensional stability. The solution offer by researchers is to add improvers in polyamides related to the application [8-11].

EPDM (also named ethylene propylene diene monomer rubber) is a mono layer membrane of synthetic rubber, which could have particular adding materials as black carbon, fibers, oils, curing agents etc., being chemically, UV and ozon. It is compatible with polar substances, as fire-resistant fluids, hot and cold water, ketones and alkalis. It is incompatible with most hydrocarbons. EPDM has outstanding resistance to heat, ozone, steam and weather. It is an electrical insulator [12, 13]. A high strain at break (over 300\%) is an adavantge of EPDM for bearing mechanical load. At $-40^{\circ} \mathrm{C}$, it keeps its properties, but other polymers loose thier elasticityand became brittle. At $+150^{\circ} \mathrm{C}, \mathrm{EPDM}$ are still providing good mechanical characteristics but many polymers are already softened. It allow for repeated elongations, but thermoplastics could fracture or not regain partially theirt shape [14].

Banerjee et al. [15] considered that mixing melt polymer components is an efficient and economical method to obtained high performance polymeric materials, but the researchers have to evaluate the influence of compatibilizing agents as without them blends could have poor mecanical properties and an ijnstable morphology $[7,16]$.

Properties of polymeric blends depend on their morphology, the adhesion quality among constituents, the surface tension and the package of properties of each constituents [17-19].

Polyamides could have impact characteristics improved by adding an elastomer or elastomer modified polymers. Frequently, in polyamides and in their blends, there were added SEBS-g-MA with clay [20-24], SEBS-g-MA+montmorillonit [25], (SEBS)+nanosilica [26], SEBS-g-MA+nano particule de carbură de siliciu [3]; NBR+clay [27], ABS [28, 29], EPDM+clay [30-32], EPDM+sepiolit [33] mEPR)+clay [34]; silicon elastomer+clay [35]; PA+(EOR)+clay [36]; elastomer etilen-co-butil acrilat/nanotalc [37], PA+PP+EPDM [38, 39], PA+EPDM [40].

Caramitu et al. [41] report on preparation and characterization of PA6/EPDM blends, for four mass concentrations: 100/0, 90/10,80/20 and 70/30. The mechanical behavior is characterized by tensile strength and compression resistance, which have proved the contribution of elastomer on the material plasticity.

The aim of this study is to evaluate the mechanical characteristics of PA6+EPDM (60/40, mass concentration) and to comparev them to those of neat PA6.

\section{Materials and methods}

General short-term mechanical properties facilitate the comparison with other materials and for refering to standards and their measuring methods, including strain-stress curves. These curves and the mechanical properties on short-term have a limited applicability in design because on long term, these values could differ, but they offer o good reference in quality control and material selection [42].

The new standard ISO 527-1 [43] does not have definitions for proportionality limit and yield limit becaus the idea of extend the linear segment of the curve was abandoned [42]. Specimens were fixed in the grips of the universal test machine INSTRON 2736-004 and pulled until failure. For ISO 527, the test speed is typically $5 \mathrm{~mm} / \mathrm{min}$ or $50 \mathrm{~mm} / \mathrm{min}$ for measuring strength and elongation and $1 \mathrm{~mm} / \mathrm{min}$ for measuring modulus. For evaluating the dynamic response of the material, researchers use other values of the test speed. In this study, the authors selected the following test speeds: $10 \mathrm{~mm} / \mathrm{min}, 250$ $\mathrm{mm} / \mathrm{min}$ and $1000 \mathrm{~mm} / \mathrm{min}$, as the test machine allow for testing at higher speeds as those in the standard [44-46].

Figure 1 presents the shape and dimensions of the specimens. 


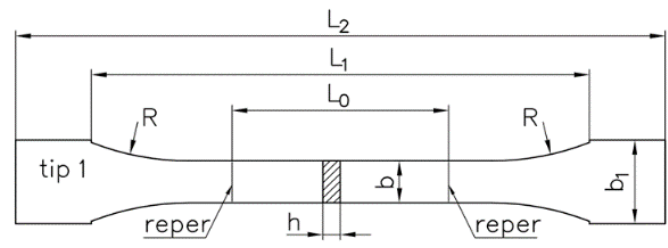

Tip 1A

$\mathrm{L}_{2} \geq 150 \mathrm{~mm}$

$\mathrm{L}_{1}=115 \mathrm{~mm}$

$\mathrm{L}_{0}=50 \mathrm{~mm}$

$\mathrm{b}=10 \mathrm{~mm}$

$\mathrm{h}=4 \mathrm{~mm}$

$\mathrm{b}_{1}=20 \mathrm{~mm}$

Figure 1. Specimen dimensions, as in SR EN ISO 527-1:2020 [43]

For tensile tests, the results could be given in:

true stress

engineering stress

$$
\sigma=F / A
$$

engineering strain

$$
\sigma_{\text {eng }}=F / A_{0}
$$

$$
\varepsilon_{\text {eng }}=\Delta L / L_{0}
$$

where $\mathrm{F}$ is the applied force on the specimen, at moment $\mathrm{t}, \mathrm{A}$ - cross section of the specimen at moment $\mathrm{t}, \mathrm{A}_{0}$ - initial cross section of the specimen, $\mathrm{L}_{0^{-}}$the initial length of the specimen between marks.

When testing polymeric matreials, conditioning is very important. The sepcimens were maintaied at $23 \pm 2^{\circ} \mathrm{C}$ and humidity $50 \pm 10 \%$, for at least $20 \mathrm{~h}$.

In literature, strain rate could be approximate with:

$$
\dot{\varepsilon}=\frac{v}{L_{0}}\left[s^{-1}\right]
$$

For the specimens used in this study the calculated values are given in Table 2:

Table 1. Calculated values for the strain rate

\begin{tabular}{|l|l|l|l|}
\hline $\begin{array}{l}\mathrm{v} \\
{[\mathrm{mm} / \mathrm{min}]}\end{array}$ & $\begin{array}{l}\mathrm{v} \\
{[\mathrm{m} / \mathrm{s}]}\end{array}$ & $\begin{array}{l}\mathrm{L} 0 \\
{[\mathrm{~mm}]}\end{array}$ & $\dot{\varepsilon}=\frac{\mathrm{v}}{\mathrm{L}_{0}}\left[\mathrm{~s}^{-1}\right]$ \\
\hline 10 & 0.000166 & \multirow{2}{*}{50} & $3.32 \times 10^{-3}$ \\
\hline 250 & 0.00416 & & $83.2 \times 10^{-3}$ \\
\hline 1000 & 0.0166 & & $332 \times 10^{-3}$ \\
\hline
\end{tabular}

There are different technologies for obtaining PA + elastomer maleate + clay blends [47, 34].

The elaboration of the recipe of this blend was based on the results of some blends based on PA and EPDM or another elastomer [48-52].

Pre-mixtures of PA6, or PA6+EPDM granules are performed in a mixer (high speed mixer), with a capacity of 2001 , mixing speed 475/950 rpm, provided with heating system with electric resistances of $11 \mathrm{~kW}$ and pneumatic discharge system. Pre-mixing of components in a mixer before being introduced into the extruder is important because the used raw materials have different densities and, implicitly, a high tendency of stratifying on density if they are not pre-mixed. Thus, a higher degree of dispersion is realized.

A pre-mixing drying stage is done by mixtures of polymer and adding material from the high-speed mixer will be placed in a drying hopper, at a temperature of $80-100^{\circ} \mathrm{C}$. The dryer is equipped with an automatic mixing loading and unloading system, with a capacity of 15001 and a working flow of 200 $\mathrm{kg} / \mathrm{h}$.

The premixtures in the drying hopper are automatically loaded into the primary dosing system. The primary dispenser has the following technical data: dosing flow $=150 \mathrm{~kg} / \mathrm{h}$, dosing system $=$ with double screw, dosing speed $=\max 100 \mathrm{rpm}$; feed hopper volume $=1501$. 


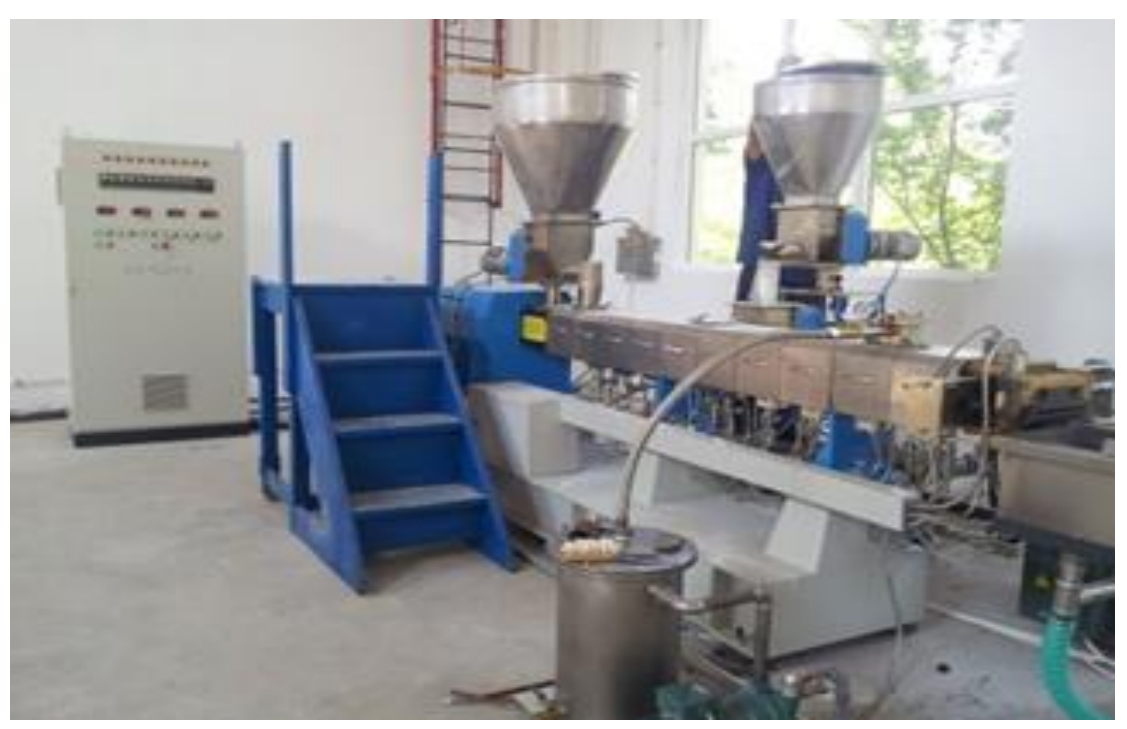

Figure 2. EC 52 double screw granulator extruder (SC Monofil Săvinești SA, Romania)

The compounding of the mixtures of polymer and EPDM was performed on an extruder type EC 52 with double screw (Figure 2), with simultaneous rotation. The extruder is equipped with a cooling system of the zones using cooled softened water, with a vacuum pump (with a power of $2.2 \mathrm{~kW}$ ), with water jacket, respectively, a hydraulic system for continuous filtration of melts provided with an engine of 1.5 $\mathrm{kW}$ and a maximum working pressure of $20 \mathrm{MPa}$. The extruder cylinder, has a modular structure, each module having a length to diameter ratio of 4 (L/D). Module 1 is provided with a supply port for additived polymeric matrices. Module 5 is provided with a hole located at the top for ventilation and/or feeding with long fibers and a side hole for dosing chopped organic or inorganic fibers and/or mineral fillings. Module 9 has a hole for the injection system.

Because the quality of the composite or thermoplastic blends depends on many factors, such as temperature, screw rotation speed, extruder length, the optimal technological parameters that will be used to make this polymer blend are indicated in Table 2 .

Table 2. Technological parameters

\begin{tabular}{|c|c|c|c|}
\hline \multicolumn{3}{|c|}{ Parameter } & \multirow{2}{*}{$\begin{array}{l}\text { Ahn [34] } \\
\text { Haake extruder with double screw with } \\
30 \mathrm{~mm} \text { diameter, wheel } 26 \mathrm{~mm} \text { and a } \\
\text { length of } 305 \mathrm{~mm} \text {. }\end{array}$} \\
\hline Machine & $\begin{array}{l}\text { Extruder ma } \\
\text { rotation, dial } \\
5 \text { types of } s \\
\text { engine powe }\end{array}$ & $\begin{array}{l}\text { ble screw with simultaneous } \\
\text { modular screw structure, with } \\
\text { xial pressure of } 4.5-5.5 \text {, main }\end{array}$ & \\
\hline $\begin{array}{l}\text { Processing } \\
\text { Zone I } \\
\text { Zone V } \\
\text { Zone IX }\end{array}$ & erature, ${ }^{\circ} \mathrm{C}^{*}$ & $\begin{array}{l}130-150 \\
240-260 \\
220-230\end{array}$ & $\begin{array}{c}240 \\
280 \text { (injection nozzle) }\end{array}$ \\
\hline \multicolumn{2}{|c|}{ Rotational speed, rpm } & 160 & 280 \\
\hline \multicolumn{2}{|c|}{ Power supply flow } & & $980 \mathrm{~g} / \mathrm{h}$ \\
\hline \multicolumn{2}{|c|}{ Mold temperature, ${ }^{\circ} \mathrm{C}$} & $80 \ldots 90$ & 80 \\
\hline \multicolumn{2}{|c|}{$\begin{array}{l}\text { Injection pressure } \\
\text { maximum pressure }\end{array}$} & 50 bar & 70 bar \\
\hline \multicolumn{2}{|c|}{ Maintenance pressure } & 20 bar & 35 bar \\
\hline \multicolumn{3}{|c|}{ Maintenance pressure time in mold for cooling, $\mathrm{s}$} & 9.0 \\
\hline
\end{tabular}

* Working temperature on the 3 zones (from 9 available on the equipment)

\section{Results and discussions}

Figure 3 presents the samples made of PA6m after being tested in traction, under different test rates. 

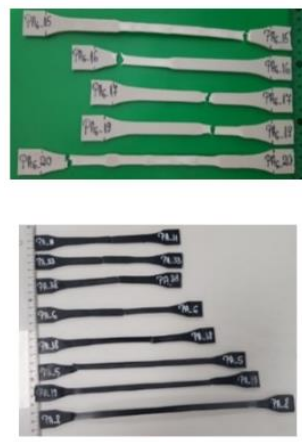

a) $10 \mathrm{~mm} / \mathrm{min}$

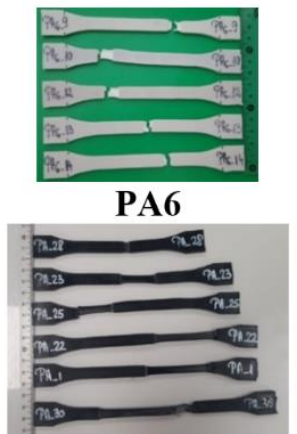

PA6+EPDM

b) $250 \mathrm{~mm} / \mathrm{min}$
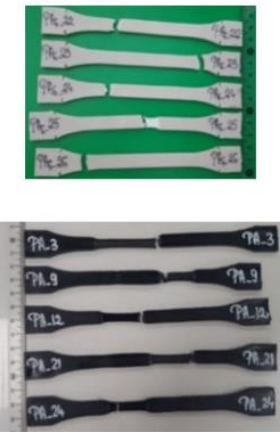

c) $1000 \mathrm{~mm} / \mathrm{min}$

Figure 3. Broken tensile specimens at different test speeds

From Figure 4, one may notice that the polymer and the blend have the proprotinality zone very well contured, the line being overlapping, but when the proportionality limit is overpassed, the curves differentiate and the material behavior is less predictible. This means that in the vasco-plastic domain (for impact resistant application) the design should be done with larger safety coefficient.

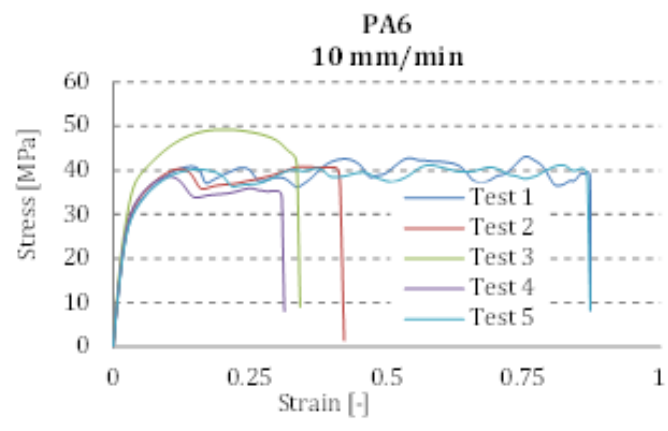

PA6

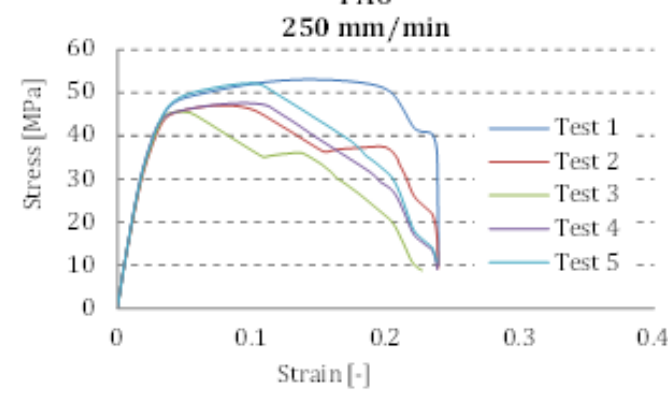

PA6

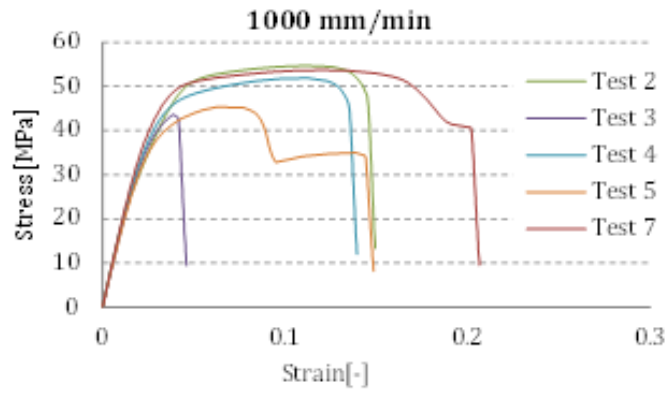

a) Stress- strain curves for PA6
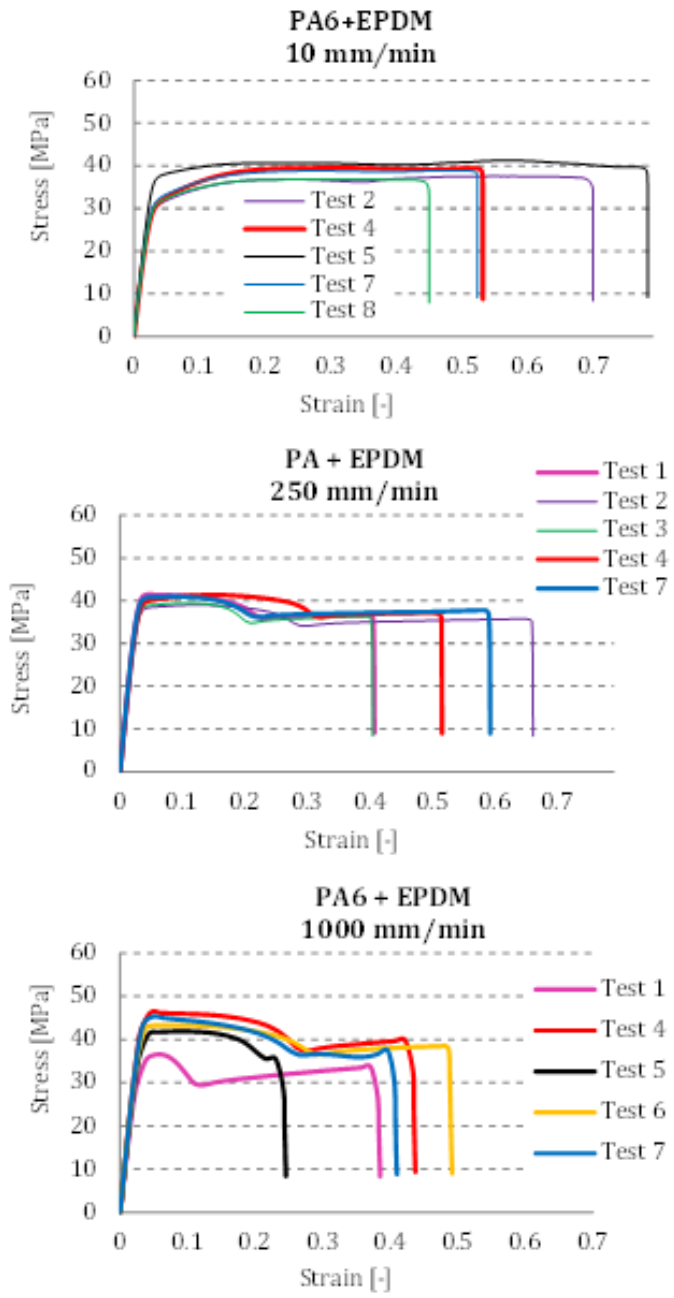

b) Stress- strain curves for $60 \% \mathrm{PA} 6+40 \%$

Figure 4. Curbe tensiune-deformație pentru materialul PA6

At $10 \mathrm{~mm} / \mathrm{min}$, sample PA6_20 was excluded, but it was kept in the photo for underlining the very diferentiated behavior of the samples, from break with small necking and elongation at break to 
specimens with large elongation and multiple necking to specimens that broke outside the marked zone. Specimens made of PA6+EPDM could be grouped in specimens with low strain at break (40\%) and in specimens with very large elongation (more than 80\%). Comparing stress-strain curves of the tested materials for test speed of $10 \mathrm{~mm} / \mathrm{min}$ (Figure 4, first line), one may notice that adding EPDM in PA6 decreases and levels the palstic yield plateaux of the specimens.

When testing at $250 \mathrm{~mm} / \mathrm{min}$ (Figure 4, second line), PA6 has a proprtionality domain maintain or all specimens but the plastic behavior is very different, even if two zones could be point out, one of almost constant stress in yielding and one with different slopes till break. This is why component made of polyamide 6 are not recommended to be designed outside the proprotionality domain. The blend has a similar proportionality line, but yielding process under load is similar for all the tested specimens, meaning its behavior in this domain is more predictible.

At the highest test speed (here, $1000 \mathrm{~mm} / \mathrm{min}$, Figure 4 third line), the materials behave as under test speed of $250 \mathrm{~mm} / \mathrm{min}$, but with curves are more spread in the plastic domain.

Both materials have large strain-at-break intervals, the largest being for the lowest test speed (10 $\mathrm{mm} / \mathrm{min})$.

Table 3 presents the evaluation, in percentage, of the same characteristics for each material. The last line points out that energy at break has a greater decrease for the neat polymer and only $17.4 \%$.

Table 3. Relative results for mechanical characteristics, calculated as percentage difference for two values: for $10 \mathrm{~mm} / \mathrm{min}$, indexed (10) and for $\mathrm{v}=1000 \mathrm{~mm} / \mathrm{min}$, indexed (1000)

\begin{tabular}{|c|l|l|}
\hline & PA6 & PA6m \\
\hline$\frac{E_{(1000)}-E_{(10)}}{E_{(10)}} \cdot 100[\%]$ & 27.30 & 11.61 \\
\hline$\frac{\sigma_{\text {break }_{(1000)}}-\sigma_{\text {break }_{(v=10)}} \cdot 100[\%]}{\sigma_{\text {break }}(10)}$ & 20.13 & -5.01 \\
\hline$\frac{\varepsilon_{\text {break }}(1000)}{\varepsilon_{\text {break }}-\varepsilon_{\text {break }}(10)} \cdot 100[\%]$ & -77.26 & 68 \\
\hline$\frac{\Delta E_{\text {break }}(1000)}{\Delta E_{\text {break }}-\Delta E_{\text {break }}(10)} \cdot 100[\%]$ & -73.32 & $-17.4 \%$ \\
\hline
\end{tabular}

Figure 5 presents the average values of the mechanical properties and the maximum and minimum values. Adding EPDM in PA6 makes Young modulus to decrease, but it seems less affected by test speed. PA6 has a similar value as the blend at $\mathrm{v}=10 \mathrm{~mm} / \mathrm{min}$ but young modulus increases more for the other two test speeds. Also, it seems less sensitive to the speed between $250 \mathrm{~mm} / \mathrm{min}$ and $1000 \mathrm{~mm} / \mathrm{min}$.

As expected from literature related to polymer, at higher test speed the stress at break increases for PA6 but for the blend this characteristic could be insensitive to speed test as it increases with only $2 \mathrm{MPa}$ from $\mathrm{v}=10 \mathrm{~mm} / \mathrm{min}$ to $\mathrm{v}=1000 \mathrm{~mm} / \mathrm{min}$ (meaning $5.7 \%$ of the value for $\mathrm{v}=10 \mathrm{~mm} / \mathrm{min}$ ). A good mark represents the fact that spred interval is narrow for the blend.

Strain at break is similar at low speed, but at higher test speeds, the blend has higher values. The designer will be interested in energy at break when using a material for its impact resistance. Thus, analyzing Figure 5, one may notice that, at low speed, both materials have close values (90 J for PA6 and $87.7 \mathrm{~J}$ for PA6+EPDM). At higher test speed, the blend has this characteristic more than double meaning it is more adequate for impact application 

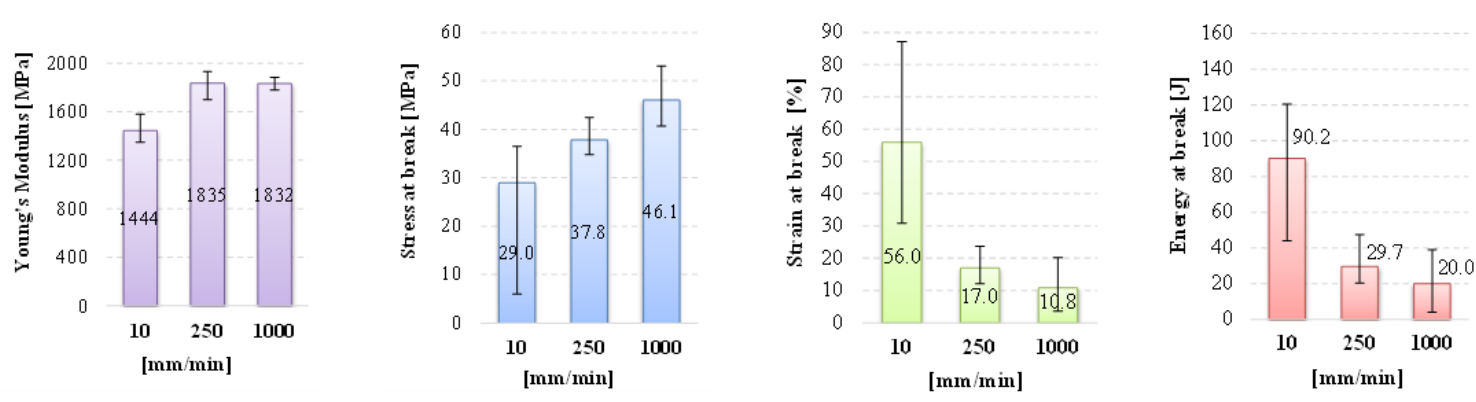

a) Mechanical characteristics for PA6
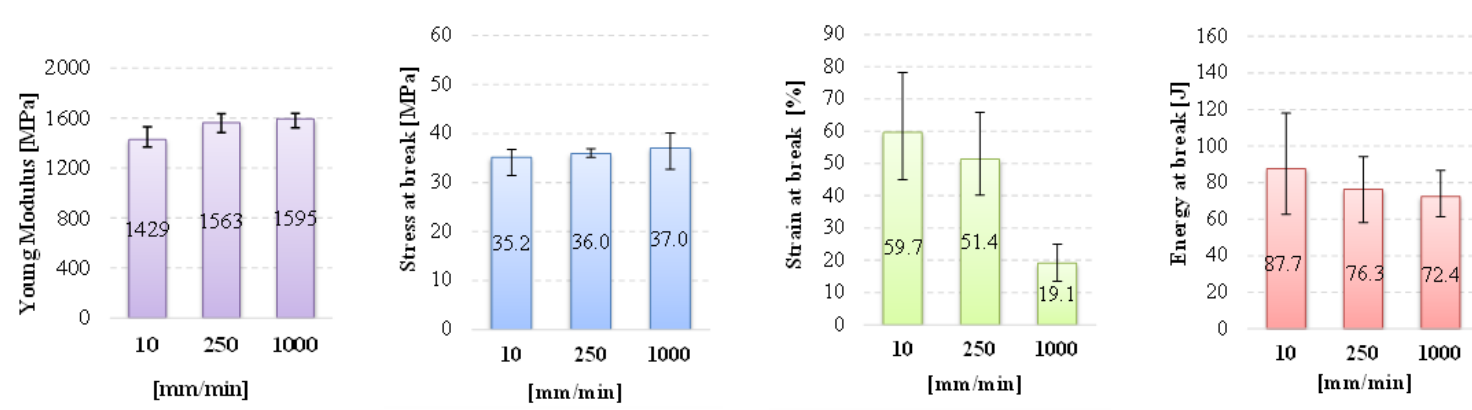

b) Mechanical characteristics for PA6+EPDM

Figure 5. Average values and spread interval of the tensile tests for the two tested materials

Figures 6, 7 and 8 present SEM images. Broken surfaces were golden coated in order to obtain a better resolution of the investigated area. Each line gives images of the same broken surface of the specimens after being tested, with different magnifications in order to point out the failure mechanisms characterizing each material.

At $10 \mathrm{~mm} / \mathrm{min}$ (Figure 6), the ductile character of PA6 and PA6+EPDM are evident, but specimens made of PA6 presents cavities due to the difficulty of injection this polymer under the processing parameters (Table 2). Crazing process is localized. Similar aspects were obtained for PA6 tested at 20 $\mathrm{mm} / \mathrm{min}$, in [17]. The blend has also local crazing but it is obvious there are no pores and the mix is quite homogenous.

Figure 7 present SEM images obtained for broken surfaces of specimens tested at $250 \mathrm{~mm} / \mathrm{min}$. Both materials present more points where break was initiated but aspect of broken surface is more uniform for the blend. For the blend. except for the conical zone where the breaks are initiated, the surface aspect of the blend is with small volumes drawn from the bulk material, elongated till break, pointing out the local ductile character, resulting a texture with elongated fibrils of several microns. These mechanism of supporting the load by local micro-deformation is beneficial for increasing the energy at break for the blend. Local crazing, as it happens in PA6, does not offer too much resistance as it is happening with small but many and relatively uniform fibrils characterizing the failure in tension of the blend. 

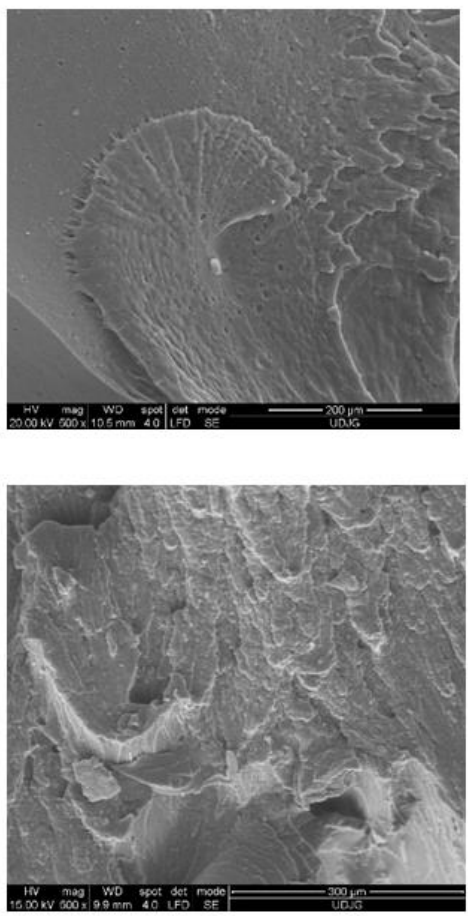

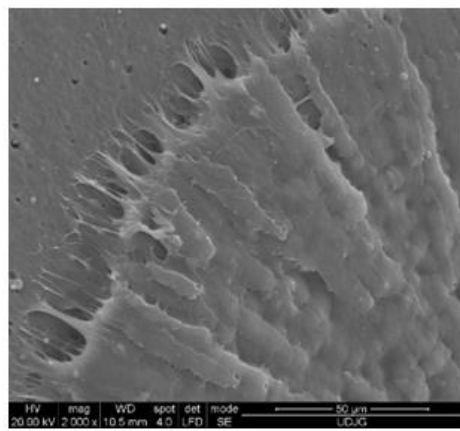

PA $10 \mathrm{~mm} / \mathrm{min}$

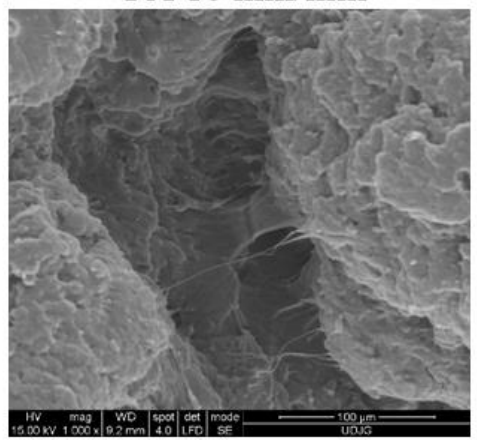

$\mathrm{PA}+\mathrm{EPDM} 10 \mathrm{~mm} / \mathrm{min}$
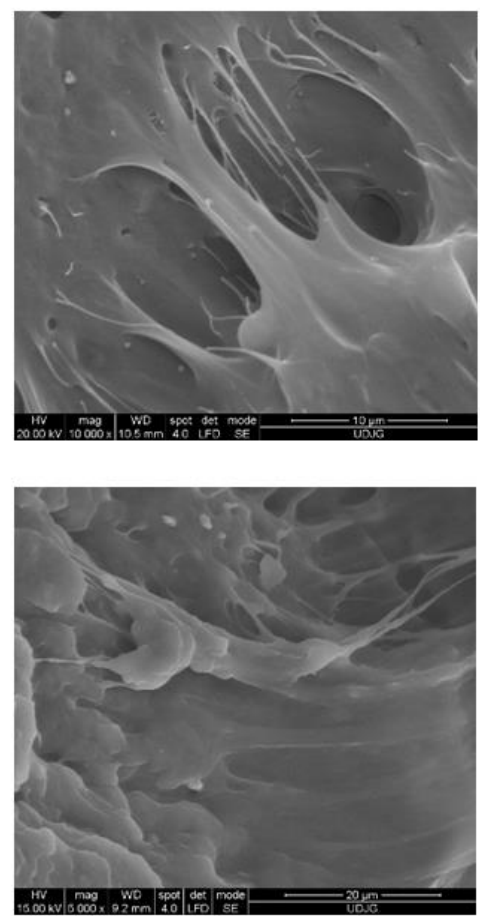

Figure 6. SEM images at different magnifications of broken surfaces at $10 \mathrm{~mm} / \mathrm{min}$
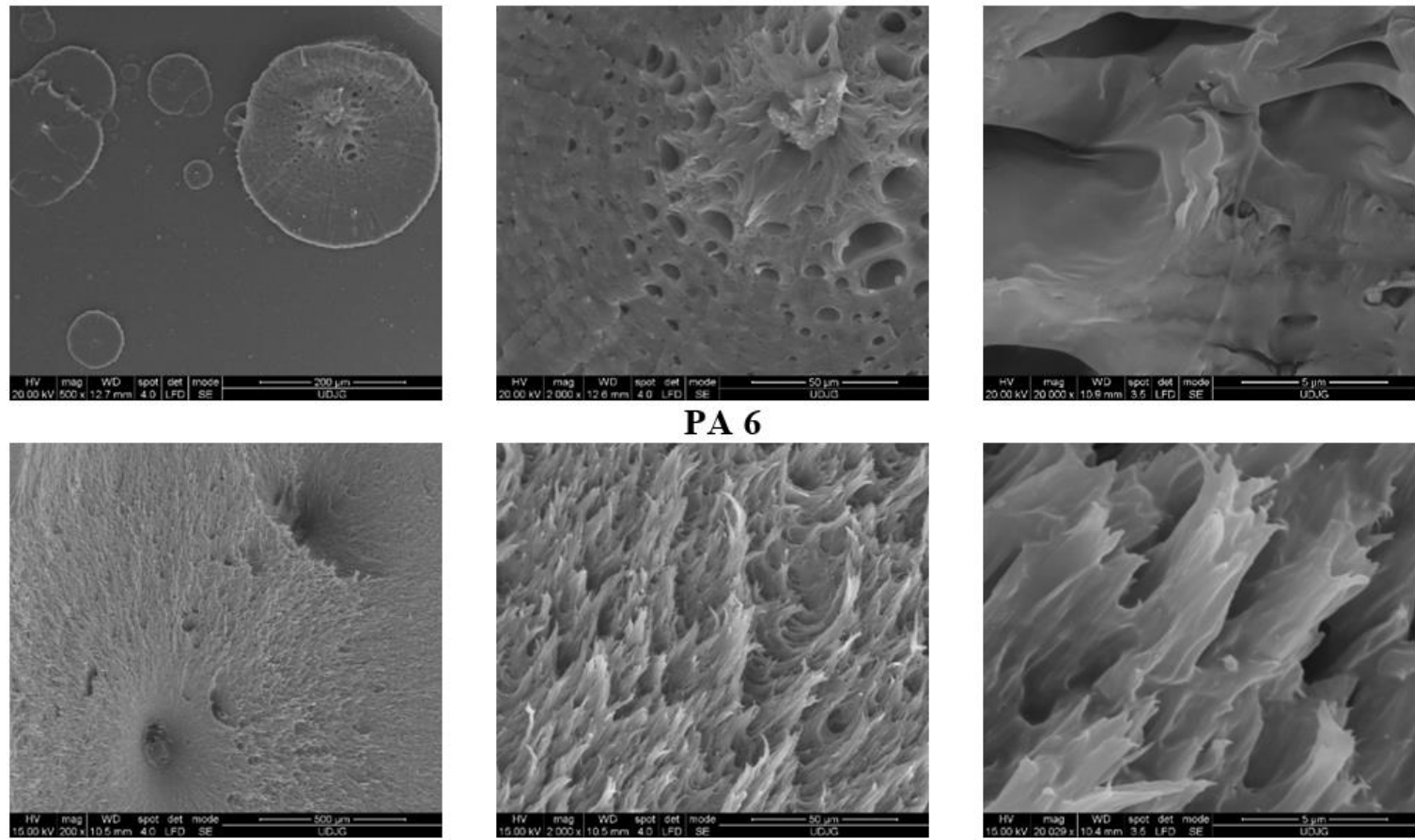

PA6+EPDM

Figure 7. Broken surface of tested material, at $250 \mathrm{~mm} / \mathrm{min}$

At $1000 \mathrm{~mm} / \mathrm{min}$ (Figure 8), the polymer presents several points where the break is initiated, but the increase in test speed generated small fibrils of polymers, or similar geometry and heights. Pores and cavities are visible on the broken surface of PA6 (the corner of the first SEM image of PA6, where the 
wall cavity is visible and also small pores). The aspect of the broken surface of the blend is similar, but with a visible more ductile character. The presence of EPDM makes the tensile load to be uniformly supported on entire cross section of the specimen.
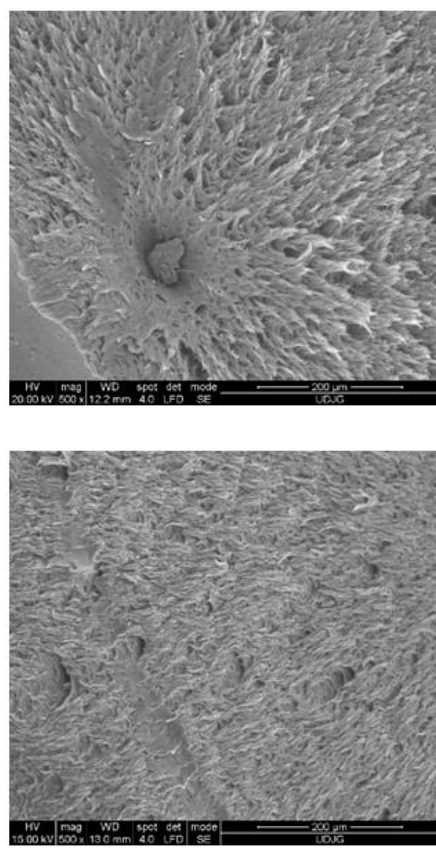

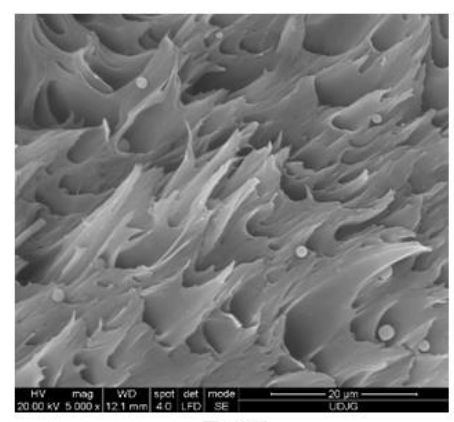

PA6

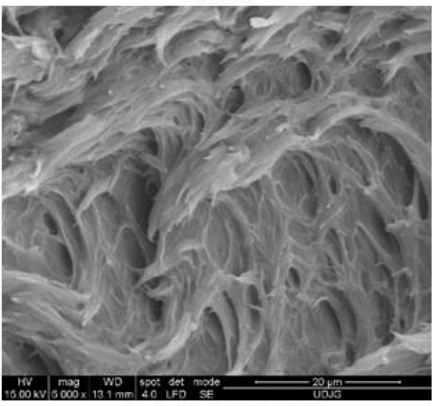

PA6+EPDM
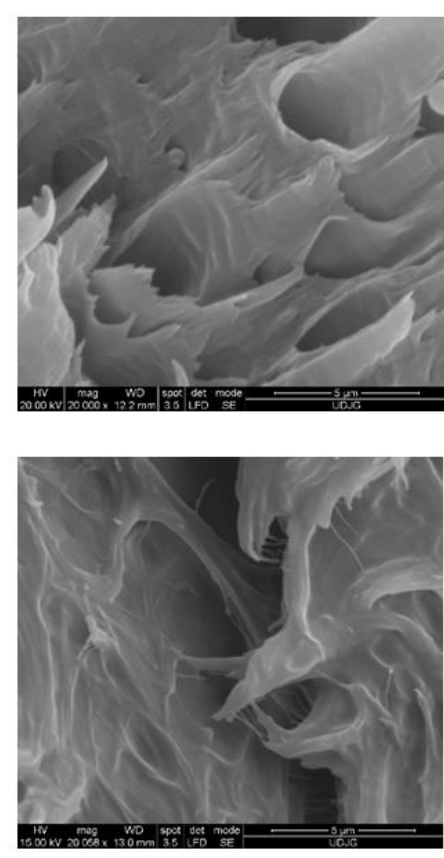

Figure 8. SEM images on break surface of a specimen at $1000 \mathrm{~mm} / \mathrm{min}$
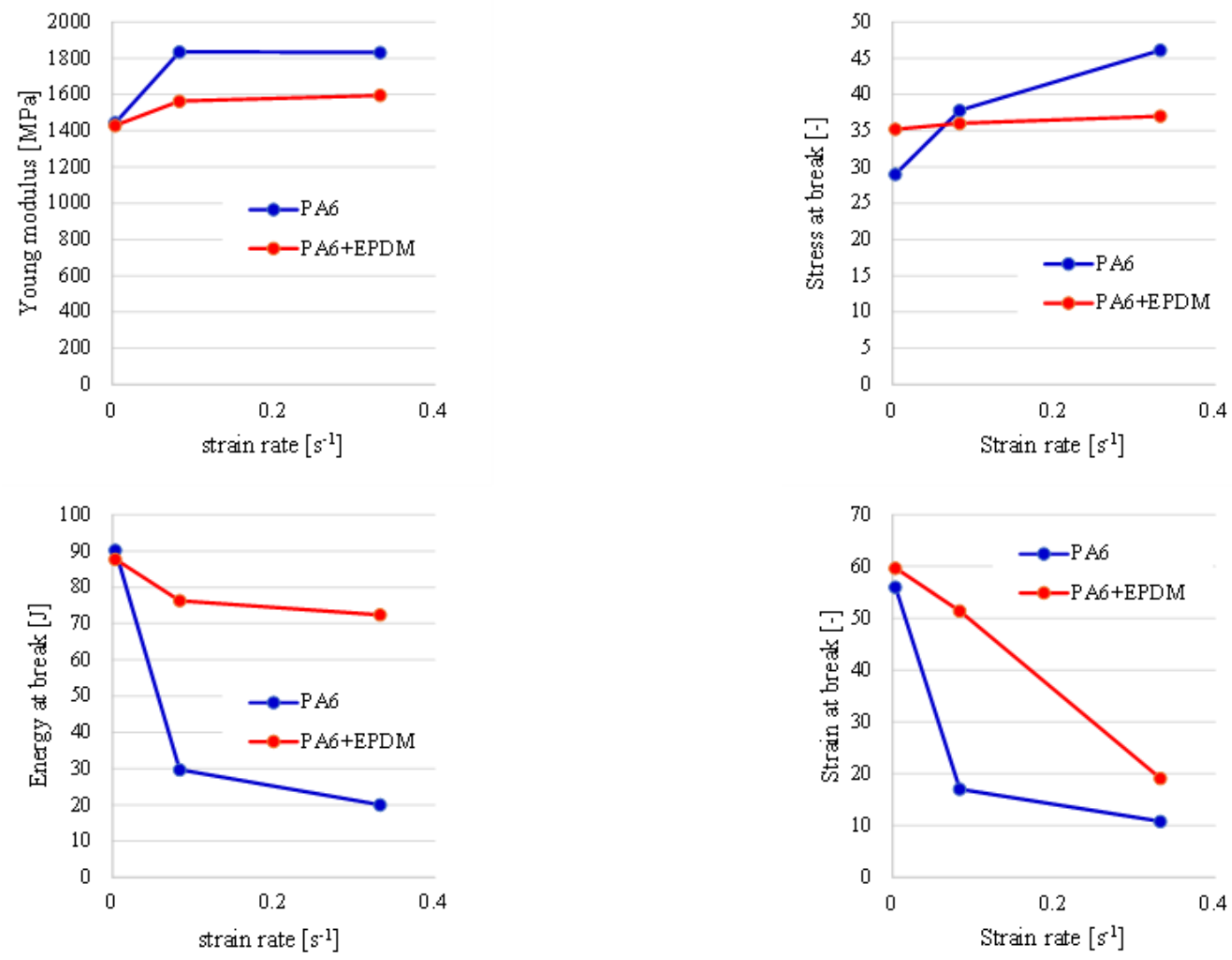

Figure 9. Comparison of mechanical characteristics for PA6 and 60\% PA6+40\% EPDM, as functions of strain rate 
Analyzing Figure 9, the following conclusions may be formulated:

- Young modulus has close value at the low test speed (1444 MPa for PA6 and 1429 for the blend, but at higher test speeds, the influence of this parameter is insignificant: PA6 keeps the average of Young modulus around 1835 and the blend around $1570 \mathrm{Mpa}$;

- the stress at break increases with test speed for PA6 but for the blend this charactertistics remains between $35 . . .37 \mathrm{Mpa}$;

- for PA6, energy at break and strain at break have a similar alure of the curve as function of strain rate, but the blend has the strain at break more sensitive to strain rate;

- energy at break has higher values for the blend, meaning that adding EPDM helps this newly formulated material to store more energy before breaking.

\section{Conclusions}

Polymeric materials are very sensitive to test speed in traction.

The blend $60 \%$ PA6 +40\% EPDM exhibit good characteristics for impact resitance application, including a higher energy at break for higher test speeds, as compared to PA6.

SEM investigation point out a homogenous structure. The blend has better value of energy at break, for the higher test speed: for $\mathrm{v}=250 \mathrm{~mm} / \mathrm{min}$ this characteristic has the value of energy at break $29.7 \mathrm{~J}$ and the blend has $76.3 \mathrm{~J}$. At $1000 \mathrm{~mm} / \mathrm{min}$, PA6 has this charcateristic of $20 \mathrm{~J}$, but for the blend, it is almost insensitive for the two higher test speeds $(76.3 \mathrm{~J}$ at $250 \mathrm{~mm} / \mathrm{min}$ and $72.4 \mathrm{~J}$ at $1000 \mathrm{~mm} / \mathrm{min}$, respectively) as compared to the neat polymer that decreases this feature when the test speed increases. At the lowest teste speed, the values of energy at break for the materials in this study are close (90.2 J for PA6 and $87.7 \mathrm{~J}$ for the blend). The results from tensile tests pointed out that the formulated blend is recommended for impact resitance applications.

The injection molding technology was the same for PA6 and the blend, but specimen quality was better for the blend, several specimens made of neat polymer having cavities. EPMD in the proportion used by the authors helps improving the impact resitance (expressed by energy at break), with acceptable consequences on other mechanical characteristics.

Acknowledgments: This work is supported by the project ANTREPRENORDOC, in the framework of Human Resources Development Operational Programme 2014-2020, financed from the European Social Fund under the contract number 36355/23.05.2019 HRD OP /380/6/13 - SMIS Code: 123847. The authors appreciate the support of eng. Doina Constantinescu, $\mathrm{PhD}$, for the documentary and producing the specimens by mold injection.

\section{References}

1.AKKAPEDDI, K., Commercial polymer blends, in Polymer blends handbook, editor Utracki LA, vol. 1, Kluwer Academic Publishers, 2002, p. 1063

2.UTRACKI, L.A., Polymer Blends Handbook, Kluwer Academic Publishers, Dordrecht, London, 2002, ISBN 1-4020-1114-8 Set

3.LIAO, C.Z., TJONG, S.C., Mechanical and thermal behaviour of polyamide\&6/silicon carbide nanocomposites toughened with maleated styrene-ethylene- butylene-styrene elastomer. Fatigue and Fracture of Engineering. Materials and Structures, 35, 2011, 56-63

https://doi.org/10.1111/j.1460-2695.2011.01561.x

4.XAVIER S.F., Chapter 10. Properties and Performance of Polymer Blends, in Utracki L.A., Wilkie CA (eds.), Polymer Blends Handbook, Springer Science+Business Media Dordrecht, 2014 https://doi.org/10.1007/978-94-007-6064-612

5.LIAO, H.Y., LI, Y.Q., LIU, C.L., TAO G.L., A Polymethylvinylsiloxane/Low Density Polyethylene Blending Melt: Dynamic Rheological Behavior and Relaxation Time, Academic Journal of Polymer Science 3(5), 2020, AJOP.MS.ID.555621 
6.IPPOLITO, F., RENTSCHA, S., HÜBNERB, G., CLAYPOLEC, T., GANE, P., Influence of calcium carbonate on polyamide 12 regarding melting, formability and crystallization properties, Compos. Part B-Eng. 164, 2019, 158-167

7.ROBESON, L.M., Polymer Blends: A Comprehensive Review, Hanser. Gardner, Munich, Germany, 2007

8.CHOW, W.S., MOHD ISHAK, Z.A., Polyamide blend-based nanocomposites: A review. eXPRESS Polym Lett 9(3), 2015, 211-232, https://doi.org/10.3144/expresspolymlett.2015.22

9.CHOW, W.S., MOHD ISHAK, Z.A., ISHIAKU, U.S., KARGER-KOCSIS, J., APOSTOLOV, A.A., The effect of organoclay on the mechanical properties and morphology of injection molded polyamide\&6/polypropylene nanocomposites, J of Appl Polym Sci 91, 2004, 175-189,

http://doi.org/10.1002/app.13244

10.JOSE, S., FRANCIS, B., THOMAS, S., KARGER-KOCSIS, J., Morphology and mechanical properties of polyamide 12/polypropylene blends in presence and absence of reactive compatibiliser, Polymer 47, 2006, 3874-3888

11.MCKEEN, L.W., The effect of temperature and other factors on plastics and elastomers, William Andrew Inc., 2008

12.RAVISHANKAR, P.S., Treatise on EPDM, Rubber Chemistry and Technology. 85, 2012, pp. 327349, https://doi.org/10.5254/rct.12.87993

13.CIESIELSKI, A., An introduction to rubber technology, Rapra, 1999.

14.***EPDM rubber, https://en.wikipedia.org/wiki/EPDM_rubber, 2021.

15.BANERJEE, S., JOSHI, M., GHOSH, A.K., Investigations on clay dispersion in polypropylene/clay nanocomposites using rheological and microscopic analysis, J Appl Polym Sci 130, 2013, 4464-4473, https://doi.org/10.1002/app.39590

16.SHARMA, K.R., Polymer Thermodynamics Blends, Copolymers and Reversible Polymerization, CRC Press Taylor \& Francis Group, 2012.

17.BOȚAN, M., Mechanical and Tribological Characterization of a Class of Polymeric Composites (in Romanian), PhD thesis, "Dunarea de Jos" University, Galati, Romania, 2014.

18.PANAITESCU, D.M., FRONE, A.N., NICOLAE, C., Micro- and nano-mechanical characterization of polyamide 11 and its composites containing cellulose nanofibers, Eur Polym J 49, 2013, 3857-3866. 19.SHEN, C., ZHOU, Y., DOU, R., WANG, W., YIN, B., YANG, M., Effect of the core-forming polymer on phase morphology and mechanical properties of PA6/EPDM-g-MA/HDPE ternary blends, Polymer 56, 2015, 395-405.

20.FARAHANI, R.D., AHMAD RAMAZANI S.A., Melt preparation and investigation of properties of toughened poly - amide\&66 with SEBS-g-MA and their nanocomposites, Materials and Design, 29, 2008, 105-111, https://doi.org/10.1016/j.matdes.2006.11.018

21.GOnZÁleZ, I., EGUIAZÁBAL, J.I., NAZÁBA, L. J., Compatibilization level effects on the structure and mechanical properties of rubber-modified polyamide-6/clay nano -composites. J Polym Sci Pol Phys, 43, 2005, 3611-3620, https://doi.org/10.1002/polb.20663

22.GONZÁLEZ, I., EGUIAZÁBAL, J. I., NAZÁBAL, J., Effects of the processing sequence and critical interparticle distance in PA6-clay/mSEBS nanocomposites, Eur Polym J 44, 2008, 287-299

https://doi.org/10.1016/j.eurpolymj.2007.11.027

23.GONZÁLEZ, I., EGUIAZÁBAL, J.I., NAZÁBAL J., Rubber toughened polyamide\&6/clay nanocomposites. Compos Sci Technol 66, 2006, 1833-1843,

https://doi.org/10.1016/j.compscitech.2005.10.008

24.WU, H., ORTIZ, R., KOO, Jh., Rubber toughened flame retardant (FR) polyamide 11 nanocomposites Part 1: the effect of SEBS-g-MA elastomer and nanoclay, Flame Retardancy and Thermal Stability of Materials 1, 2018, 25-38, https://doi.org/10.1515/flret-2018-0003

25.TJONG, S.C., BAO, S.P., Impact fracture toughness of polyamide-6/montmorillonite nanocomposites toughened with a maleated styrene / ethylene butylene/styrene elastomer. J Polym Sci Pol Phys 43, 2005, 585-595. 
26.ZHANG, B., WONG, J.S-P., SHI, D., YAM, R.C-M., LI, R.KY., Investigation on the mechanical performances of ternary nylon 6/SEBS elastomer/nano-SiO 2 hybrid composites with controlled morphology. J Appl Polym Sci 115, 2010, 469-479, https://doi.org/10.1002/app.30185

27.JAHROMI, A.E., AREFAZAR, A., JAZANI, O.M., SARI, M.G., SAEB, M.R., SALEHIL, M., Taguchi-based analysis of polyamide\&6/acrylonitrile-butadiene rubber/nanoclay nano -composites: The role of processing variables. J Appl Polym Sci 130, 2013, 820-828

https://doi.org/10.1002/app.39191

28.ARAUJO, E.M., HAGE, E.J.R., CARVALHO, A.J.F., Acrylonitrile-Butadiene-Styrene Toughened Nylon 6: The Influences of Compatibilizer on Morphology and Impact Properties, J Appl Poly Sci 87, 2003, 842-847.

29.ZHOU, L., WAN, Y., CHEN, X., SUN, S., ZHOU, C., Toughening of PA6 nanocomposites by reactive acrylonitrile- butadiene-styrene core-shell rubber particles. Polym Composites 35, 2014, 864 871, https://doi.org/10.1002/pc.22730

30.GARCÍA-LÓPEZ, D., LÓPEZ-QUINTANA, S., GOBERNADO-MITRE, I., MERINO, J.C., PASTOR, J.M., Study of melt compounding conditions and characterization of polyamide $6 /$ metallocene ethylene-polypropylene-diene copolymer/maleated ethylene-polypropylene-diene copolymer blends reinforced with layered silicates. Polym Eng Sci 47, 2007, 1033-1039,

https://doi.org/10.1002/pen.20782

31.WANG, K., WANG, C., LI, J., SU, J., ZHANG, Q., DU, R., FU, Q., Effects of clay on phase morphology and mechanical properties in polyamide\&6/EPDM-g-MA/organoclay ternary nanocomposites. Polymer, 48, 2007, 2144-2154, https://doi.org/10.1016/j.polymer.2007.01.070

32.ZHANG, L., WAN, C., ZHANG, Y., Investigation on morphology and mechanical properties of polyamide 6/ maleated ethylene-propylene-diene rubber/organoclay composites. Polym Eng Sci 49, 2009, 209-216, https://doi.org/10.1002/pen.21201

33.GALLEGO, R., GARCÍA-LÓPEZ, D., MERINO, J.C., PASTOR, J.M., How do the shape of clay and type of modifier affect properties of polymer blends? J Appl Polym Sci 127, 2013, 3009-3016 https://doi.org/10.1002/app.37979

34.AHN, Y-C., PAUL, D.R., Rubber toughening of nylon 6 nanocomposites. Polymer 47, 2006, 2830 2838, https://doi.org/10.1016/j.polymer.2006.02.074

35.DONG, W., ZHANG, X., LIU, Y., WANG, Q., GUI, H., GAO, J., SONG, Z., LAI, J., HUANG, F., QIAO, J. Flame retardant nano - composites of polyamide\&6/clay/silicone rubber with high toughness and good flowability. Polymer 47, 2006, 6874-6879, https://doi.org/10.1016/j.polymer.2006.07.038

36.YOO, Y., TIWARI, R.R., YOO, Y-T., PAUL, D.R., Effect of organoclay structure and mixing protocol on the toughening of amorphous polyamide/elastomer blends. Polymer 51, 2010, 4907-4915 https://doi.org/10.1016/j.polymer.2010.08.036

37.PRASATH, B.G., MAITI, S.N., Effects of nanotalc inclusion on mechanical, microstructural, melt shear rheological, and crystallization behavior of poly-amide\&6-based binary and ternary nanocomposites. Polym Eng Sci 50, 2010, 1978-1993, https://doi.org:10.1002/pen.21724

38.WANG, L., SHI, C., GUO, X.-Z., YU, J., Tailoring the morphology of polypropylene/polyamide 66 blend at an asymmetric composition by using organoclay and maleic anhydride grafted polypropylene. J Ind Eng Chem 20, 2014, 259-267.

39.MAZIDIAB, M.M., AGHJEH, M.K.R., Synergistic toughening effects of dispersed components in PP/PA6/EPDM ternary blends; quantitative analysis of the fracture toughness via the essential work of fracture (EWF) methodology, The Royal Society of Chemistry, RSC Adv., 5, 47183-47198, 2015 https://doi.org/10.1039/C5RA07193C

40.MA, L., YANG, W., GUO, H., Effect of cross-linking degree of EPDM phase on the morphology evolution and crystallization behavior of thermoplastic vulcanizates based on polyamide 6 (PA6)/ ethylene-propylene-diene rubber (EPDM) blends, Polymers 11, 2019, 1375

https://doi.org/10.3390/polym11091375 
41.CARAMITU, R., ZAHARESCU, T., MITREA, S., TSAKIRIS, V., MARINESCU, V., AVADANEI, L., PA 6/EPDM Blends for Electrical Insulations. Preliminary Characterization, The 8th International Symposium on Advanced Topics in Electrical Engineering, May 23-25, 2013, Bucharest, Romania.

42.BROWN, R., Handbook of Polymer Testing. Short-Term Mechanical Tests, Rapra Technology Limited, 2002, Shawbury.

43.*** SR EN ISO 527-1:2020 Plastics. Determination of tensile properties. Part 1: General principles

44.*** Instron soft, https://www.instron.us/en-us/products/materials-testing-software, 2021.

45.*** Universal Testing Systems, https://www.instron.us/en-us/products/testing-systems, 2021.

46.***Handbook INSTRON CEAST 9340,

https://www.instron.us/-/media/literature-library/products/2010/02/ceast-9300-series.pdf?la=en-US, 2021.

47.LI, H., XIE, X-M. Morphology development and superior mechanical properties of PP/PA6/SEBS ternary blends compatibilized by using a highly efficient multi-phase compatibilizer. Polymer 108, 2017, $1-10$.

48.MA, L., YANG, W., GUO, H., Effect of Cross-Linking Degree of EPDM Phase on the Morphology Evolution and Crystallization Behavior of Thermoplastic Vulcanizates Based on Polyamide 6 (PA6)/Ethylene-Propylene-Diene Rubber (EPDM) Blends, Polymers, 11, 1375, 2019

https://doi.org/10.3390/polym1109137

49.MUSTEAȚ Ă, A.E., Characterization of Two Families of Polymeric Blends Based on PA6 and PP by Tensile and Charpy Tests, PhD Thesis, "Dunarea de Jos" University, Galati, Romania, 2020.

50.HASANPOUR, M., MAZIDI, M.M., AGHJEH, M.K.R., (2019) The effect of rubber functionality on the phase morphology, mechanical performance and toughening mechanisms of highly toughened PP/PA6/EPDM ternary blends, Polym Test 79, 2019

https://doi.org/10.1016/j.polymertesting.2019.106018

51.SUN, A., WANG, Y., WANG, B., CAO, Y., WANG, J., YANG, Y., Toward largely enhanced toughness and balanced strength in PA1012/EPDM blends via synergistic effect of sacrificial bonds and network structure, Macromol. Mat. Eng., 306(5), 2021, https://doi.org/10.1002/mame.202000813

52.HUA, Y.L., QIAN, L.Y., CHUN, L.L., GUO, L.T.A., Polymethylvinylsiloxane/Low Density Polyethylene Blending Melt: Dynamic Rheological Behavior and Relaxation Time, Academ. J. Polym. Sci., 3(5), 2020, 555621, https://DOI.org/10.19080/AJOP.2019.03.555621

$\overline{\text { Manuscript received: } 26.07 .2021}$ 